DANKO ČUREPIĆ, Ph.D.

Traffic Infrastructure

E-mail: danko.curepic@t.ht.hr

Review

T - HT

Avenija Dubrovnik 26, HR-10000 Zagreb,

Accepted: May 15, 2008

Republic of Croatia

Approved: Sep. 16, 2009

ZDRAVKO TOŠ, Ph.D.

E-mail: tosz@fpz.hr

University of Zagreb,

Faculty of Transport and Traffic Sciences

Vukelićeva 4, HR-10000 Zagreb, Republic of Croatia

\title{
TECHNICAL DOCUMENTATION IN TRAFFIC TECHNOLOGY
}

\begin{abstract}
The requirements for the prompt usage of traffic infrastructure capacities define the technological frames which ensure updated maintenance and development of new traffic infrastructure capacities by implementing graphical and computer systems. Technical documentation (TD) based on the technology of geographic information systems (GIS) allows fast analysis of graphical and alphanumerical data with the aim of identifying spatial relations among various cartographic elements. The paper analyses and presents the methodological bases of building GIS with the aim of designing the traffic network topology, as well as structural and functional analysis which uses the acquired knowledge to propose concrete solutions on connecting data about the position of infrastructure facilities with their properties in the railway traffic safety.
\end{abstract}

\section{KEY WORDS}

technical documentation, geographic information system, structural and functional analysis, software for technical drawing, signalling devices, railway

\section{INTRODUCTION}

The traffic technology studies the technological factors (procedures and principles) of the traffic process in order to efficiently overcome the space and time differences in the movement of the traffic participants.

TD is a sum of alphanumerical and graphical data that represent the infrastructure facilities and capacities, and their current position in space. The main function of TD is efficient usage, maintenance and management of the existing technological potentials and serves as a platform for the definition of the development objectives, criteria and methods for the evaluation of designs and making crucial business decisions related to the development of the technological systems.
The topic has been selected in order to improve rail traffic safety, and to enhance the designs and programs of the development of the traffic control and management systems as key elements of the information and communication systems.

Past research as well as knowledge from practice have only partly answered the questions regarding this complex and slightly neglected issue, i. e. the correlation of the problematic domain of managing the information and communication systems (databases) and spatial data in GIS environment in the Republic of Croatia had not been sufficiently recognized.

By structural and functional analysis and by evaluating the existing traffic solutions, the base is being created to find improvements, with the aim of raising the level of traffic safety and quality. The compatibility of information and communication, and spatial data in the GIS system means the capability of the systems to function, i. e. work together. To solve the basic tasks in geography, the GIS technology has been designed and it models and analyses the spatial data.

In the development of human skills the cartography has been present for more than 4000 years. During this time, a whole series of techniques has been developed to ensure the clarity of communication with simultaneous maximisation of the contents of the used maps. The existing and new computer programs have to accumulate knowledge from cartography. This means that the strenuous work of the cartographer is free of repetitive actions and superfluous activities, thus letting the cartographer focus on adequate unique human visual capabilities for the interpretation and design of the contents.

The traffic science inevitably has to use cartography, as well as the acquired knowledge in the field. This paper deals with the synergy of action in using the cartographic data in traffic. 


\section{DESCRIPTION OF TECHNICAL DOCUMENTATION}

\subsection{Purpose and activities of the technical documentation service}

In every traffic and technological system which deals with the above-mentioned or similar activities, TD has to be the source of reliable and updated information for the development, design, providing consent and production of technical solutions, maintenance, exploitation and legal security of the infrastructure traffic systems. It has to present the existing infrastructure capacities and their current position in space. In order to keep the state of the infrastructure capacities updated, all the changes of infrastructure elements in space or capacity have to be promptly registered and entered into the TD.

The basic activities of the traffic infrastructure owner's TD service include:

- recording of the completed condition of the laid infrastructure systems, and producing of documentation based on the subcontractor's studies,

- receipt and control of TD,

- detailed control of the received geodetic studies from other geodetic organisations,

- collection of geodetic documents for the production and updating of TD,

- entry of data about the system elements into the information system,

- distribution of TD data,

- harmonisation of the entered data with other related organisation units exclusively for border parts of the traffic system routes,

- TD updating,

- archiving of TD and cadastre studies.

The companies have to collect updated geodetic documents and plans for the production of TD infrastructure, either for the incomplete existing one, and for the new one, with the purpose of exact infrastructure description.

The geodetic maps and plans serve for the purpose of planning, design and production of the completed TD, maintenance of infrastructure systems and procedures in solving the property-rights relations.

The TD data are distributed to:

- the cadastre of infrastructure facilities - exclusively studies for the cadastre without the symbols of facilities on the traffic system infrastructure,

- traffic capacities development service,

- design organisations - exclusively for the sections of routes and capacities which are to be changed or which are in collision with the planned route,

- maintenance service,

- rescue and security coordination service,
- service of economic activities - financial data on the constructed capacities,

- legal service - data for the purpose of legal protection of the existing and new infrastructure capacities.

\subsection{Significance of technical documentation}

Within every transport-oriented company, in the narrow sense TD represents the basis for rational, commercial and technologically efficient usage, maintenance, and control and management of technological potentials used by the company.

In the methodology of computer-aided development of TD high standards have already been achieved (e. g. ACAD). Consequently, there is need to unify the software tools and define the symbols that are used in drawings of standardized formats (e. g. dwg).

Such approach substantially shortens the time of writing and modifying the documentation, thus updating it and raising its quality. TD is a service to the majority of services and departments at companies since it combines the information produced by each one of them individually into a unique system for controlling the condition of infrastructure capacities and services provided by the company to the users.

In listing all the advantages of the production, storage and presentation of documentation using computer technologies, the following may be highlighted:

- substantial shortening of the time needed to make the documentation,

- documentation is maximally updated,

- documentation is always available (on-line) to all the necessary services,

- usage of documentation is unambiguous regardless of the type of requested data.

In using the Internet for technical documentation, the focus should be placed on three basic elements:

- unlimited quantity of information,

- almost unlimited freedom of access to data,

- user-friendliness and ease of connection.

\subsection{System for registering and reading technical documentation}

For technical documentation in the graphical form, the most widespread software currently is the one for technical drawings, AutoCAD ${ }^{\circledR}$ of the Autodesk ${ }^{\circledR}$ company, representing the acronym for computer-aided drawing.

The success of this program is said to be due to its open architecture in using object vectorisation, which means that the contents of many files is used by AutoCAD ${ }^{\circledR}$ as plain text, which can be relatively sim- 
ply adjusted to specified needs of producing technical documentation. Support provided by AutoCAD ${ }^{\circledR}$ to foreign languages, including those that use other scripts, is significant, which makes it a unique standard for technical drawing. Also, the support of AutoLISP ${ }^{\circledR}$, the symbolic programming language LISP, which is adjusted to AutoCAD ${ }^{\circledR}$ requirements, was also a significant factor in using AutoCAD ${ }^{\circledR}$ as a standard for professional technical drawing.

AutoCAD ${ }^{\circledR}$ is a flexible program for graphical analysis of technical characteristics of the objects, applicable to all the areas that use technical drawing. The program covers almost all the areas of technical drawings and is used almost everywhere in the world.

The main disciplines that use the AutoCAD ${ }^{\circledR}$ software package include:

- architecture,

- transport,

- mechanical engineering,

- production management,

- electricity/electronics,

- multimedia.

The basic tools for devising TD at companies that construct and maintain their infrastructure capacities is the AutoCAD ${ }^{\circledR}$ Map (geographically oriented tools) which allows implementation of tools functionality adjustment to the needs of working with geo-referenced documents, by using the object-oriented programming language Visual Basic for Applications (VBA) [6].

\subsection{Availability of data and storing of technical documentation}

Data on infrastructure facilities and capacities, as well as the related databases according to their character are classified as confidential documentation. The misuse of such documentation is to be sanctioned since it is the exclusive right of the owner.

When introducing new information systems the owner expects the availability and acceleration of the provision of data and easier takeover of data from other users.

One of the problems that need to be recognized and solved is the problem of safety and security. The integrity of data has to be protected against unintentional or intentional interventions by unauthorized users. The majority of security mechanisms has already been installed into the already exiting sub-segments of information systems. The security is realised usually through software, i. e. combination of either system, or applicative solutions written by the user. The security of this type solves the majority of problems related to logging in, running of certain critical applications, as well as availability of data from the database.

Saving TD data in the electronic form should be insured by adequate space on the server, thus protecting the integrity, availability, and authenticity of data, as well as the confidentiality from the aspect of access and protection against unauthorized usage.

Safety and security have to explicitly define the types of users who may successively:

- have access to the computer,

- have access to certain applications (programs),

- have access only to certain types of data.

In the transport and technological systems which own a large number of infrastructural capacities (e. g. $\mathrm{HZ}$ ), the work with the existing TD and databases is limited to individual types of users:

- for the design and construction of some other capacities (only data on capacity routes - situations are available),

- for external designers who design changes in the infrastructure, e. g. protection of the existing capacities against high voltage (data on route, type and year of installation of a certain capacity are available),

- for the designers of the parent company, in maintenance, i. e. external subcontracted design agency (data on infrastructure facilities and capacities are available, as well as certain part of data from the base related to the above-mentioned activities),

- information system that has the accessibility level only within the company, and related to the user data defined by the information system administrator,

- GIS, which has data accessibility level only within the company, defined by the TD administrator.

\section{GEOGRAPHIC INFORMATION SYSTEM AS THE CENTRAL SYSTEM OF PHYSICAL DATA}

\subsection{The most important characteristics of the geographic information system}

GIS is a system composed of hardware, software and geo-coded database, i. e. physical data and the respective interpretation data, representing at the same time the technology which collects the physical and other data, and allows the analysis of data in a fast and efficient way, data handling, and their storage in order to create new information as the output product, primarily in the graphical form (dwg).

The mentioned systems use complex structures of data in order to be able to describe the physical objects and their interrelations.

The most important characteristic of GIS is the possibility of spatial analyses, realised by relating data from space to other sources using the location as the basic common key. The result of this procedure is sim- 
ple visualisation and location of the observed data in user-friendly manner.

The basic purpose of GIS is not the production of maps, although it may create maps in various scales, projections and colours, but GIS is rather an analytic system whose main advantage is to enable identification of spatial relations among cartographic elements.

For the implementation of the GIS system a well-done preparation is important, which allows digitisation of infrastructural objects and capacities, and the related user locations. The methodological basis of the GIS system is the following:

- space document (digital ortophoto in M 1:5000; in RH almost entirely produced, presenting the actual condition at the time of recording) and map geo-coding,

- addresses and coordinates (x, y, z in Gauss-Krüger coordinate system) of the existing and future users of infrastructural objects or capacities,

- connecting of alphanumerical and graphical data,

- presentation of all the requested data on the web,

- digitisation of infrastructural and user locations with unknown addresses.

\subsection{Information system of the technical documentation based on geographic and information system}

GIS uses the browser in the Internet network with expanded functionality of traditional databases, and represents the basis for TD production and usage (Figure 1).

The GIS browser is also related to the operation and the respective traffic information, e. g. infrastructure and services, i. e. records in the GIS system database which require correlation with unique geographic position. This connection allows the GIS browser to limit its search results regarding the user-defined geographic criteria (e. g. macro or micro presentation). Moreover, GIS browser can be combined with real-time display of information. Therefore, the browser shows basically the position of the object, but,

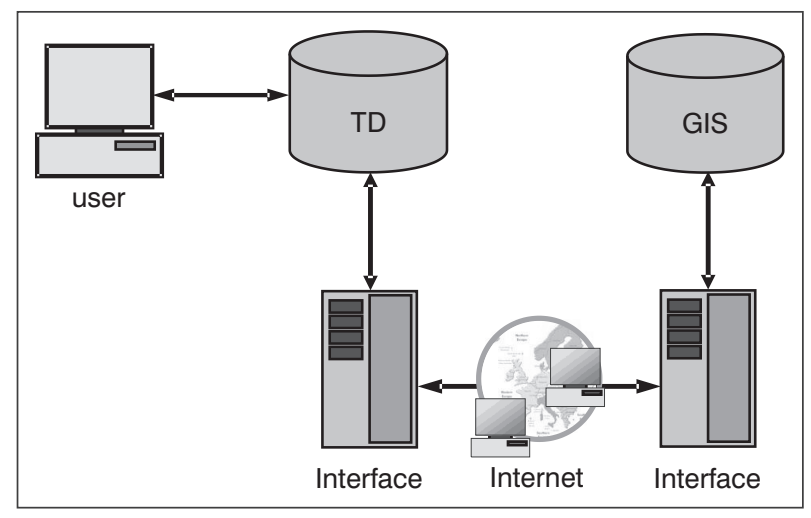

Figure 1 - Data exchange from GIS at request it can also display additional information. In other words, the browser can enable the expansion of information. Such information for producing the technical documentation can be distinguished from a simple text to full web page, depending on the work requirements.

In producing the technical documentation for the Croatian territory, due to the curvature of the Earth the information about the space are mapped onto two ellipsoid-transversally positioned cylinders along the $15^{\text {th }}$ and $18^{\text {th }}$ meridians (the so-called Gauss-Krüger conformal ellipsoid projection onto elliptical cylinders). For the needs of conversion from the space into plane display, the data about the geographical latitude and longitude need to be transformed for the Republic of Croatia into the Gauss-Krüger coordinate system.

The territory of the Republic of Croatia is mapped onto two coordinate systems, the fifth and the sixth from the Greenwich meridian $\left(3^{\circ}\right.$ between the border meridians). In each of these coordinate systems $\mathbf{x}$ axis is the contact meridian $\left(15^{\circ}\right.$ and $\left.18^{\circ}\right)$ with positive direction northwards, and $\mathbf{y}$ axis is the contact parallel $\left(43^{\text {rd }}\right.$ to $46^{\text {th }}$ ) in relation to the equator.

The parallels with $\mathbf{x}$ axis (meridian) at a distance of $22.5 \mathrm{~km}$ divide the area of each system into columns, and the parallels with $\mathbf{y}$ axis at a distance of $15 \mathrm{~km}$ (parallel) divide the area into rows. Since there must not be any negative ordinates $\mathbf{y}$ in the mapping area, the value of $+500,000 \mathrm{~m}$ is added to the $\mathbf{x}$ axis (meridian). Consequently, all the $\mathbf{y}$ ordinates with a lower value will lie to the west, and those with a higher value to the east of $\mathbf{x}$ axis.

Before ordinate $\mathbf{y}$, the number of the system which includes the point is placed first, instead of a million, so that the $\mathbf{x}$ axes have ordinate $5,500,000 \mathrm{~m}$ in the fifth system and $6,500,000 \mathrm{~m}$ in the sixth system.

The first row (the southernmost) begins with abscissa $\mathbf{x}$ in the fifth system with the value of $4,755,000 \mathrm{~m}$, and in the sixth system with the value 4,635,000m (Figure 2) [3].

An important task in the transport technology is the planning of the urban public traffic network and identification of underserved areas as well as the defining of improvement of the level of transport services. Due to the restrictions on the analysis procedures, the planners use individual indicators, e. g. of the traffic flow density, in order to evaluate the entire network traffic service. However, serious drawbacks are noted in the assessment of individual indicators such as:

- areas with poor transport service which cannot be efficiently found using the classical methods,

- area in which the relation between the demand and availability of public transport service has not been fully considered. 


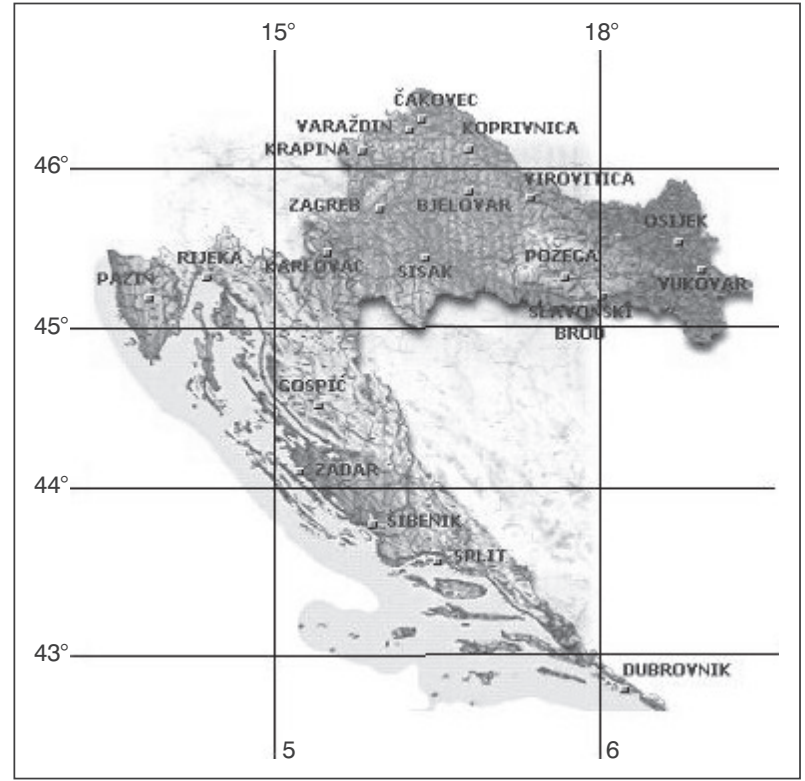

Figure 2 - Territory of the Republic of Croatia in Gauss-Krüger conformal projection

The transport models require large quantities of data such as: network traffic topology, network capacity, traffic data related to the area or travel matrices, etc. GIS has become a handling tools for most of these data that may facilitate the procedure of planning and improve the transport quality. However, transport models require complex topology that had not been covered well by the traditional GIS topologies. A possible solution lies in the working procedure which significantly facilitates the work on using higher programming languages, particularly designed for GIS in special applications:

- semi-automatic procedures implemented for the mapping of the transport areas and the focus for the traffic network,

- methods for processing the data from the traffic nodes, including automatic connection of node data and the links between them,

- geographic coordination of the traffic networks and public transit networks, and

- methods for the processing of many alternative projects applicable at the network level.

For the automation of the planning process of the traffic network topologies the ArcGIS program system of the ESRI Company is mostly used with program modules ArcInfo and ArcView. Moreover, these modules can be used for the analysis of the public transport network in the traffic models. In this procedure the work is significantly facilitated by the usage of higher-level programming languages such as Arc Macro Language-AML and Avenue.

The traffic models use two types of data or variables, and these are the ones in which traffic depends on the characteristic explaining variables and traffic data, used for the evaluation and correction of the models. The explaining variables are usually divided into variables (or data) that describe the need to travel, and often the expression traffic potential or transport demand (social and economic variables) is used, and traffic network-connected variables that describe the resistance against traffic (traffic resistance), also often called delivery-oriented variable of the traffic models.

Technical documentation may describe the traffic network by means of complex topology including links, nodes, divergings (e. g. defined in the schedule), travel routes (e. g. defined by means of dynamic segmentation) and changes between travel paths at railway stations. Moreover, the traffic models will often contain different networks, e. g. road, water, rail and public transport network. Some of these networks have been completely defined (e. g. buses, trains and aircraft), and some have been only partially defined (taxis, boats, etc.), and sometimes the networks are completely segregated (e. g. highways from railways, aircraft from ships). For a certain trip it is important whether geographical data are used from different traffic networks (e. g. how to arrive to the railway station by bicycle, to a city by train, to a bus stop on foot, to a ship by bus).

\section{IMPLEMENTATION OF GEOGRAPHIC AND INFORMATION SYSTEMS AT RAILWAYS}

\subsection{Railway telecommunications}

Most of the railway traffic operates on the main railway lines, and many railway lines are deflecting sections of the main network and possibly end in the terminal railway station. Since the rail route returns back toward the main railway network, the absence of other connecting possibilities can limit the selection for providing the flexibility function to the information transfer system. All the rail authorities mainly have their own transfer systems, but the use of non-railway systems of transfer services can be required. This may be realised by the use of non-railway radio connections or non-railway cable or possibly by services from the public telecommunication operator network. The transfer systems of public telecommunication operators are often different from the railway systems. They tend to be subjected to the capacities, with wider frequency bands and higher data transfer speeds, and they serve large numbers of subscribers or customers, using highly efficient radial systems based on the local and central switching.

The telecommunication traffic services are mainly delivered by means of "closed" or independent, that 
is, functional railway telecommunication systems. If the services are delivered from the "open" (possibly public telecommunication operator) systems, then they have to fulfil the additional conditions or controls (including risk assessment).

In order to realise continuous control of railway infrastructure facilities as well as mobile traffic means, adequate TD is necessary. In order to use TD adequate information systems are inevitable. Similarly to other telecommunication systems, it is possible to use data and information from other information systems. Here, a particularly important connection is towards the specific databases (e. g. cadastre of cables) which already contain cadastre data both of railway infrastructure facilities, and the data of the owners of various infrastructures in the railway line environment.

All the data on railway telecommunication network need to be found in the databases of the authorized government institutions. Thus, for instance, track should be kept on the data regarding the stationary-infrastructural facilities of general significance (railway line routes, bridges, stations, telecommunication networks). It is very important here that the data are kept separated according to the level of significance, just as the access to these data has to be selected in compliance with the requirements for big transport companies [1].

\subsection{Technical documentation in rail traffic safety}

This paper studies the implementation results when data on the position of mandatory signals at the West Railway Station in Zagreb are used. Using available location methods of home signals (geodetic recording by total station and system for satellite positioning by the GPS device) their position has been verified. The research has combined the data on the position of the infrastructural facilities with their characteristics in the function of railway traffic safety.

Light signal in the present railway signalisation is of extreme importance in the system of safety-signalling devices. It has the characteristic of emitting certain signals for the regulation of train operation, and belongs to the group of infrastructural facilities. For the analysis of the properties it is necessary to pre-define their position, which has been traditionally done by determining the "kilometre position" on a certain railway line (Figure 3). Since the line geometry changes over time, this data certainly fails to be reliable. In order to solve this problem the system of absolute object position in the coordinate system and the exact above-the-sea level has to be applied, and for this GIS and geodetic measurements by total station can be used.

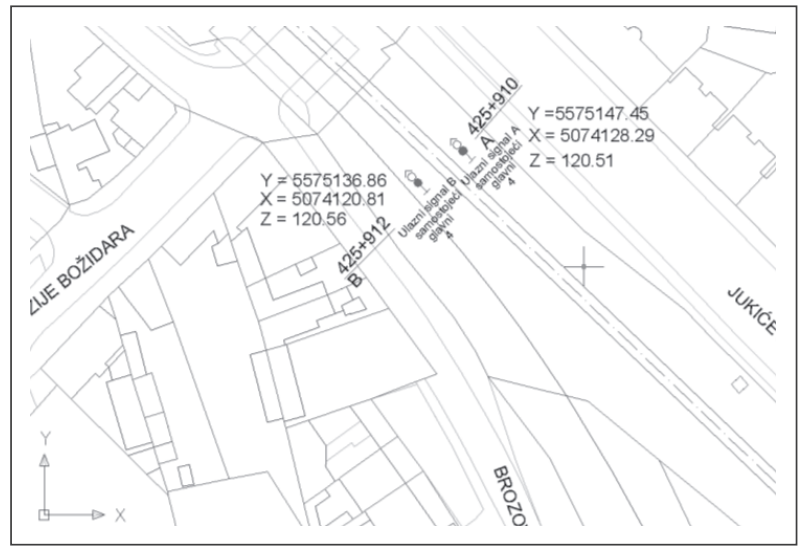

Figure 3 - Position of rail signals in GIS

The development of the database started from the digital geodetic document, in which exact coordinate input signals of the railway stations have been entered. For this type of objects a new database was created in ArcGIS with the respective symbols and their attributes. The key to the development of the automatic procedure for plotting on the map was the production of a centralised geo-database which contains geographical and technical data of the object.

After the cartographic additional processing and control of the entered data a graphical preparation for map plotting was made.

Based on the data taken in real time from the safety-signalling device at the West Railway Station, a new database in real time was created in which the object attributes in real time could be variable, in accordance with the emission of signal notions at home signals. Thus the data from the TD of the station after having been processed could be sent via wireless connection to the locomotive which approaches the home signal.

Using the GPS receiver onboard locomotive these data can be presented in the drivers cab by using adequate graphical interface in accordance with the locomotive position.

The emitted signal notions refer to the train receiving them, and running on a certain railway line. This means that apart from transferring the data on the train movement, also the information about its position need to be transferred to the control centre. During research the interaction of data about the object (e. g. signal A) and the current information on the sig-

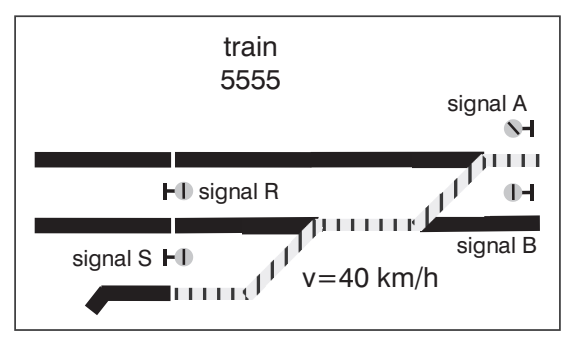

Figure 4 - Information on train movement 
nal notion was carried out. Using the GPS receiver onboard locomotive, the information from GIS on the position of the signal and the data from the safety-signalling device, the requested information about the object was obtained (Figure 4).

\section{CONCLUSION}

In accordance with the set research objectives the methods and unique software tools for documenting and planning of infrastructure facilities and capacities in the field of rail traffic technology have been recognized. This results in fast and simple access to data required to maintain the traffic infrastructure facilities and rail line capacities, and in finding of free railway line capacities by using the database and physical planning.

The empirical data from TD indicate the necessity of applying the verified methods that will ensure high-quality technical support in all other segments important for the functioning of the traffic and technological systems.

In the GIS domain an automated process can be used for designing the traffic network topology. The use of this developed methodology may be useful in creating numerous traffic models of mid-size urban areas to metropolitan areas.

The information obtained from GIS for tracking trains (in time and space) is in correlation with the information supplemented by signalling sign and the non-occupancy of the rail track in front of the train. The analysis of using the location data on the position of the main signals on the rail indicates the need for interactive connection of data on the object and the information on the signal notion emitted by this object. The intention is to stimulate integration of the user interfaces and GIS in all the traffic areas [4].

The TD analysed in this work, as integral system in traffic and technological sense aims to increase the utilisation level of traffic capacities and improve the traffic safety. By ensuring the backbone for configuring, implementing, and integrating the information services, the users are provided with reliable and precise information and the system must at the same time ensure an acceptable level of integration and continuity of operation. This work can serve also as incentive to creating legal regulations related to the storage of important data of general significance into the databases of the authorised government institution.
Dr. sc. DANKO ČUREPIĆ

E-mail: danko.curepic@t.ht.hr

T - HT

Avenija Dubrovnik 26, 10000 Zagreb, Republika Hrvatska

Dr. sc. ZDRAVKO TOŠ

E-mail: tosz@fpz.hr

Sveučilište u Zagrebu, Fakultet prometnih znanosti

Vukelićeva 4, 10000 Zagreb, Republika Hrvatska

\section{SAŽETAK}

\section{TEHNIČKA DOKUMENTACIJA U FUNKCIJI TEHNOLOGIJE PROMETA}

Zahtjevi za promptnim korištenjem prometnih infrastrukturnih kapaciteta definiraju tehnološke okvire u kojima se implementiranjem grafičkih $i$ računalnih sustava osigurava ažurno održavanje i razvoj novih prometnih infrastrukturnih kapaciteta. Tehnička dokumentacija (TD) temeljena na tehnologiji geografskih informacijskih sustava (GIS) omogućava brzu analizu grafičkih i alfanumeričkih podataka s ciljem identifikacije prostornih odnosa između raznih kartografskih elemenata. U radu su analizirane i prikazane metodološke osnove izgradnje GIS sustava s ciljem konstruiranja prometne topologije mreže, kao i strukturna i funkcijska analiza kojom se iz dobivenih spoznaja predlažu konkretna rješenja o povezivanju podataka o položaju infrastrukturnih objekata s njihovim svojstvima u funkciji sigurnosti željezničkog prometa.

\section{KLJUČNE RIJEČI}

tehnička dokumentacija, geografski informacijski sustav, strukturna i funkcijska analiza, program za tehničko crtanje, signalni uređaji, željeznica

\section{LITERATURE}

[1] Toš, Z., Čurepić, D., Kovačić, Z.: Specific characteristics of construction and technical documentation of tc networks, ZIRP Conference, Zagreb, 2003

[2] Gold, H., Kos, V., Nemec, D., Toš, Z., Trajbar, K.: Informacijski sustavi u željezničkom prometu, Faculty of Transport and Traffic Sciences, Zagreb, 1993

[3] Macarol, S.: Praktična geodezija, Tehnička knjiga, Zagreb, 1978

[4] Čurepić, D.: Kompatibilnost sustava upravljanja telekomunikacijskom mrežom i inteligentnim transportnim sustavima, Doctoral dissertation, Faculty of Transport and Traffic Sciences, Zagreb, 2006

[5] http://www.ESRI.com

[6] http://www.Autodesk.com

[7] http://www.fer.hr

[8] http://www.science.direct.org 